\title{
Financial inclusion and its impact on performance of MSMEs with efficiency and financial flexibility as mediation: Empirical evidence from Malang City
}

\author{
K. Ratnawati \\ Faculty of Economics and Business, Brawijaya University, Malang, Indonesia
}

\begin{abstract}
This study analyzes the effect of financial inclusion on the performance of MSMEs and examines the role of mediation efficiency and financial flexibility. The simple random sampling technique was used with a total of 100 respondents and analyzed using partial least square (PLS). The results showed that financial inclusion had an effect on the performance of MSMEs, both directly and through mediation, namely, financial efficiency and flexibility. Increased financial inclusion has a major impact on improving the performance of MSMEs through efficiency, rather than through financial flexibility. Increasing access to financial services for MSMEs, which increases with increased efficiency in the form of a financial service approach to MSMEs, will improve the performance of MSMEs.
\end{abstract}

\section{INTRODUCTION}

MSMEs are a vital sector for the Indonesian economy (Zain, 2010); the number of MSME units in Indonesia comprises $99.99 \%$ of the total business actors (Kementrian Koperasi dan UMKM RI, 2017). Abdmoulah and Jelili (2013), Chauvet and Jacolin (2017), Lee et al. (2019), Khan (2011), and Morgan and Pontines (2014) examined the impact of financial inclusion on the growth of MSMEs in developed and developing countries, which shows that financial inclusion has a positive and significant effect on company performance and growth. According to Khan (2011) and Morgan and Pontines (2014), financial inclusion reduces liquidity barriers and encourages investment, thereby increasing output and employment opportunities. The proper implementation of financial inclusion can increase the economic activities of MSMEs (Egbetunde, 2012; Martinez, 2011; Mbuotor and Uba, 2013; Okafor, 2012; Onaolapo, 2015; Yaron et al, 2013). However, the latest research conducted by Ejiofor et al. (2020) firmly concludes that financial inclusion has no effect on the growth of MSMEs. The results of the research by Ejiofor et al. (2020) are in accordance with the findings of Awoyemi, Ogunyikamni, and Akamolafe (2015), which also state that financial inclusion has no effect on the performance of MSMEs. This shows the inconsistency of findings related to the effect of financial inclusion on the performance of MSMEs. According to Rifa'i (2017), it is difficult for MSMEs to get financed flexibly from formal financial institutions because their business background can be categorized as unbankable.

Research related to the effect of financial inclusion on the growth of MSMEs has been conducted by several researchers, namely, Abdmoulah and Jelili (2013), Banarjee (2014), Chauvet and Jacolin (2017), Lee et al. (2019), Khan (2011), and Morgan and Pontines (2018). Several other studies have also concluded that proper implementation of financial inclusion can increase economic activity, including improving the performance of MSMEs (Egbetunde, 2012; Goodland, Onumah, and Amadi, 2012; Khan, 2011; Martinez, 2011; Mbotor and Uba, 2013; Okafor, 2012; Onaolapo, 2015; Yaron, Benjamin, and Piprek, 2013). 
Hypothesis 1: Financial inclusion has a positive and significant effect on the performance of MSMEs.

According to Mardiasmo (2009), efficiency is closely related to the concept of productivity. Efficiency indicators describe the relationship between resource inputs by an organizational unit (e.g., staff, wages, and administrative costs) and the resulting output. The greater the output compared to the input, the higher will be the level of efficiency of an organization (Mardiasmo, 2009). Ergungor (2006); Kempson et al., (2004); and Grohman et al. (2017) have examined the relationship between financial inclusion and efficiency in developing countries.

Hypothesis 2: Financial inclusion has a positive and significant effect on efficiency.

Financial flexibility is one of the most interesting themes these days. This is because of a survey conducted by Graham and Harvey (2001), and the results obtained from 392 chief financial officers (CFOs) from various companies in America showed that financial flexibility is the most important factor in determining the composition of the capital structure. According to Byoun (2008), financial flexibility shows the level of capacity and the speed of a company in mobilizing its financial resources or taking preventive, reactive, and exploitative actions in order to maximize the firm value.

Hypothesis 3: Financial inclusion has a positive and significant effect on financial flexibility. Hypothesis 4: Efficiency has a positive and significant effect on the performance of MSMEs.

Kevane and Wydick (2001) also stated that providing credit to MSMEs encourages economic growth through increase of business capitalization, creation of job opportunities, and long-term income growth. More credit means more company formation and hence economic growth (Aghion and Bolton, 1997). On the other hand Brown et al. (2005) and Chauvet and Ehrhart (2018) found that access to external credit will substantially increase sales growth and company growth (Banarjee, 2014). Dimitrov and Tice (2006) reveal that credit constraints, either due to bad credit or a recession, can encourage companies to experience lower sales growth rates.

Hypothesis 5: Financial flexibility has a positive and significant effect on the performance of MSMEs.

According to Okafor (2012) and Nurjannah (2017), financial inclusion can accelerate the flow of credit to MSMEs and support the growth of MSMEs. MSMEs without access to affordable credit will experience difficulties in expanding their business (Donati, 2016). Calcagnini et al. (2014) show that collateral easily allows companies to access credit, especially to reduce payment costs. Mishkin (2007) noted that efficiency through opening of many bank branches and the entry of new financial service providers in the financial market can pave the way for the provision of varieties of financial products and services that are in accordance with the needs of MSMEs, which was confirmed by Chandan and Mishra (2010), who observed that the presence of an institutional structure for financial services such as offices, branches, and personnel resulted in increased access to financial services by MSMEs. Fafchamps and Schündeln (2013) found evidence that there is a significant relationship between the availability of local banks and faster growth for MSMEs.

Hypothesis 6: Financial inclusion has a positive and significant effect on the performance of MSMEs with efficiency as a mediator.

Hypothesis 7: Financial inclusion has a positive and significant effect on the performance of MSMEs with financial flexibility as a mediator. 


\section{RESEARCH METHODS}

Determination of the sample in this study was done using Roscoe's theory reported by Saidani, Rachman, et al. (2013) by determining a sample of 100 MSMEs in Malang City. The data were collected using the simple random sampling method and analyzed using PLS.

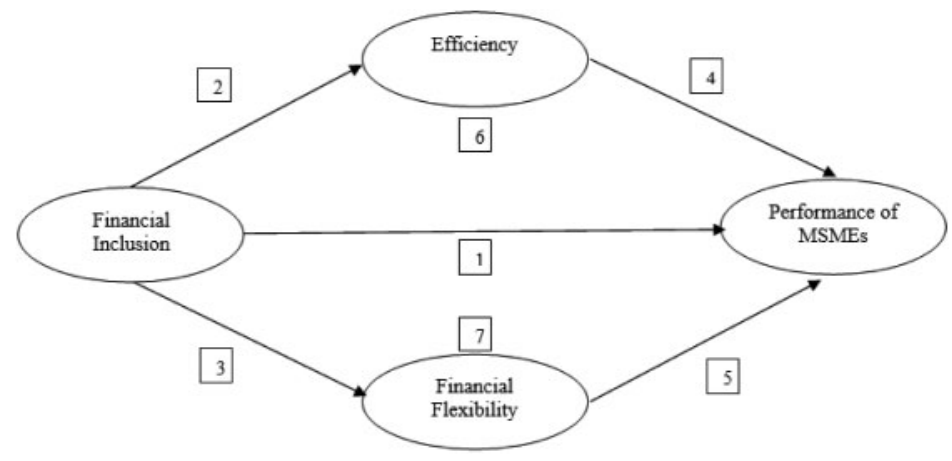

Figure 1. Research framework

\section{RESULT AND DISCUSSION}

\subsection{Research result}

The outer model test results show that all variables can be said to be valid and reliable and can be used for further analysis. Hypothesis testing is presented in Table 1.

Table 1. Hypothesis testing

\begin{tabular}{|c|c|c|c|c|c|}
\hline & $\begin{array}{l}\text { Original } \\
\text { Sample } \\
\text { (O) }\end{array}$ & $\begin{array}{l}\text { Sample } \\
\text { Mean } \\
\text { (M) }\end{array}$ & $\begin{array}{l}\text { Standard } \\
\text { Deviation } \\
\text { (STDEV) }\end{array}$ & $\begin{array}{l}\text { T Statistics } \\
(\mid \mathbf{O} / \text { STDEV } \mid)\end{array}$ & $\begin{array}{l}\mathbf{P} \\
\text { Values }\end{array}$ \\
\hline Financial inclusion $\rightarrow$ performance of MSMEs & 0.870 & 0.876 & 0.012 & 91.660 & 0.000 \\
\hline Financial inclusion $\rightarrow$ Efficiency & 0.876 & 0.868 & 0.017 & 76.281 & 0.000 \\
\hline Financial inclusion $\rightarrow$ Financial Flexibility & 0.862 & 0.875 & 0.015 & 82.779 & 0.000 \\
\hline Efficiency $\rightarrow$ Performance of MSMEs & 0.841 & 0.847 & 0.014 & 69.011 & 0.000 \\
\hline Financial flexibility $\rightarrow$ Performance of MSMEs & 0.882 & 0.895 & 0.010 & 36.892 & 0.000 \\
\hline $\begin{array}{l}\text { Financial inclusion } \rightarrow \text { Efficiency } \rightarrow \\
\quad \text { Performance of MSMEs }\end{array}$ & 0.795 & 0.876 & 0.022 & 95.008 & 0.000 \\
\hline $\begin{array}{l}\text { Financial inclusion } \rightarrow \text { financial flexibility } \rightarrow \\
\text { Performance of MSMEs }\end{array}$ & 0.836 & 0.937 & 0.013 & 78.683 & 0.000 \\
\hline
\end{tabular}

Source: Output PLS, 2020

\subsection{Discussion}

Financial inclusion has a significant positive effect on the performance of MSMEs, which is in line with several previous studies conducted by Egbetunde (2012); Goodland et al. (2012); Khan (2011); Martinez (2011); Mbuotor and Uba (2013); Okafor (2012); Onaolapo (2015); and Yaron et al. (2013). Considered as one of the most important dimensions of financial development, financial efficiency is defined as the extent to which the financial system fulfills its functions (Olgu, 2014). This finding regarding a positive relationship between financial inclusion and efficiency is in line with that reported by García and José (2016), who argued that increased financial inclusion due to 
intensive participation in the financial system by low-income clients can lead to high transaction and information costs. Prasad (2010) also argued that at the country level, financial inclusion can increase efficiency in financial intermediation by increasing domestic savings and investment, thereby promoting economic stability.

The Encyclopedia of Business (2015) states that financial flexibility is the ability of a company to adapt to problems and opportunities and borrow money if needed (Brigham et al., 1999). Agha (2014) and Denis and McKeon (2011) considered financial flexibility as the reserve capacity for leasing credit and loans. Bergant (2015) defined financial flexibility as the ability (capacity and speed) of a business system to finance the exploitation of business opportunities without disturbing its financial stability. When faced with financing constraints, companies should prioritize debt financing at lower costs when obtaining external financing and use short-term investment and untapped loan capacity to maintain financial flexibility in order to maintain constant growth in their firm value (Yang and Zhang, 2020).

Efficiency and financial flexibility have a significant positive effect on the performance of MSMEs in Malang City, which is in line with previous research studies conducted by Mishkin (2007), Primus (2015), and Ahmad and Ali (2015). The mediation efficiency and financial flexibility have an effect on financial inclusion and the performance of MSMEs, and the results of the analysis show a significant positive effect. The results of the variable distribution analysis show that the financial inclusion is in a fairly good category, and the performance of MSMEs in Malang city also shows that Malang UMKM actors have high MSME performance.

\section{CONCLUSIONS}

Increasing financial inclusion also improves efficiency by simplifying formal credit procedures and reducing bank credit costs. Increasing efforts to build customer satisfaction and loyalty as an indicator of financial flexibility will improve the performance of MSMEs. Efforts to increase financial flexibility have the strongest influence on improving the performance of MSMEs, if it is through financial intermediation by opening banking branches, so as to improve lender and borrower relations. Increasing financial inclusion will improve the performance of MSMEs through financial flexibility and access to finance, but the impact is not as strong as through financial flexibility alone.

\section{REFERENCES}

Abdmoulah, W., \& Jelili, R. Ben. (2013). Access to Finance Thresholds and the Finance-Growth Nexus. Economic Papers: A Journal of Applied Economics and Policy, 32(4), 522-534.

Agha, Mahmoud.(2014): The Effect of Financial Flexibility and Credit Transitions on Corporate Investment and Financing Decisions. Found on internet: March 2015 http://scholargoogleusercontent.com/scholar?q= cache:L2qyOphUXCAJ:scholar.google.com/+agha + mahmoud $+\% 22$ The + effect + of + financial + flexibility + and + credit+rating + transition $\% 22 \&$ hl $=$ s1\&as_sdt $=0,5 \&$ as_vis $=1$.

Aghion, P. and Bolton, P. (1997). A Theory Of Trickle-Down Growth and Development. Review of Economic Studies. Vol. 64, pp. 151-172.

Ahmad, Syed Z. dan Arif, Afida M.M. (2015). Strengthening Access to Finance for Women-Owned SMEs in Developing Countries. Equality, Diversity and Inclusion: An International Journal, Vol. 34 Iss 7 pp. 634-639.

Bergant, Ž. (2015): Financna prožnost in naložbena sposobnost. Poslovodno racunovodstvo, Letnik, Številka $1,38-61$.

Brigham F. E., Gapenski C. L., Daves R. P. (1999): Intermediate Financial Management. 6th ed. Orlando: The Dryden Press.

Brown, J. D., Earle, J. S., dan Lup, D. (2005). What Makes Small Firms Grow? Finance, Human Capital, Technical Assistance, and the Business Environment in Romania. Economic Development and Cultural Change, Vol. 54 No. 1, pp. 33-70.

Byoun, S. 2008. How and When do Firms Adjust their Capital Structures Toward Targets? Journal of Finance. 63(6): 3069-3096. 
Calcagnini, G., Farabullini, F., dan Giombini, G. (2014). The impact of guarantees on bank loan interest rates. Applied Financial Economics, Vol. 24 No. 6, pp. 397-412.

Chauvet, L., \& Jacolin, L. (2017). Financial Inclusion, Bank Concentration, and Firm Performance. World Development, 97, 1-13.

Denis, J.D., McKeon, S.B. (2011): Debt Financing and Financial Flexibility: Evidence from Pro-active Leverage Increases. http://papers.ssrn.com//sol3/papers.cfm?abstract_id=1361171.

Dimitrov, V., dan Tice, S. (2006). Corporate diversification and credit constraints: Real effects across the business cycle. The Review of Financial Studies, Vol. 19 No. 4, pp. 1465-1498.

Donati, C. (2016). Firm Growth and Liquidity Constraints: Evidence from the Manufacturing and Service Sectors in Italy. Applied Economics, Vol. 48 No. 20, pp. 1881-1892.

Egbetunde, T. (2012). Bank credits and rural development in Nigeria (1982-2009). International Journal of Finance and Accounting, 1(3), 45-52.

Ejiofor, E., Camillus, Ok. N., \& Ubogu, F. E. (2020). Effects Of Financial Inclusion On The Growth Of Cottage Firms In Nigeria. American Research Journal of Humanities \& Social Science (ARJHSS), 3(1), 06-14.

Encyclopedia of Business. (2015): Income statements. http://www.swlearning.com/finance/maness/shortterm2e/powerpoint/ch02/sld008.htm.

Ergungor, OE., (2001). Theories of Bank Lon Commitments. Economic Review-Federal Reserve Bank of Cleveland, p.1.

Fafchamps, Marcel dan Schündeln, Matthias. (2013). Local Financial Development and Firm Performance: Evidence from Morocco. Journal of Development Economics, Vol 103 pp. 15-28.

García, M. J.R and José, M. (2016). Can financial inclusion and financial stability go hand in hand? Economic Issues, 21 (2) (2016), pp. 81-103.

Graham, J., Harvey, C. (2001). The Theory and Practice of Corporate Finance: Evidence from The Field. Journal of Financial Economics. 60(2):187-243.

Goodland, A., Onumah, G., \& Amadi, J. (2012). Rural Finance (No. 1). Chatham, U.K.

Kempson, Ruth M. (1995). Semantics. Cambridge University Press. Jakarta: Airlangga Press.

Kevane, M., Wydick, B. (2001). Microenterprise Lending to Female Entrepreneurs: Sacrificing Economic growth for Poverty Alleviation. World Development, Vol. 29, No. 7, pp. 1225-1236.

Khan, S. H. R. (2011). Financial inclusion and financial stability: are they two sides of the same coin? Indian Bankers Association \& Indian Overseas Bank, Chennai, (November), 1-12.

Lee C.-C, Wang C.-W, \& Ho S.-J. (2019). Financial Inclusion, Financial Innovation, and Firms' Sales Growth. International Review of Economics and Finance.

Mardiasmo. 2004. Efisiensi dan Efektifitas. Penerbit: Andy Jakarta

Martinez, M. V. (2011). The Political Economy of Increased Financial Access. Georgetown University.

Mishkin, Frederic S. (2008). Ekonomi, Uang, Perbankan dan Pasar Keuangan. Edisi 8.Buku 2. Jakarta: Salemba Empat.

Morgan, P. J., \& Pontines, V. (2014). Financial Stability and Financial Inclusion. In ADBI Working Paper Series (No. 488). Tokyo: East Asian Bureau of Economic Research.

Nurjannah, Laila. (2017). Peran Inklusi Keuangan Terhadap Perkembangan UMKM di Yogyakarta. UIN Sunan Kalijaga Yogyakarta.

Okafor, F. O. (2012). Financial Inclusion: An Instrument for Economic Growth and Balanced Development in Rural Areas. Journal of the Chartered Institute of Bankers of Nigeria, 6(8), 38-45.

Olgu, O. (2014). Handbook of Research on Strategic Development and Regulatory Practice in Global Finance. IGI Global.

Onaolapo, A. R. (2015). Effects of financial inclusion on the economic growth of Nigeria. International Journal of Business and Management Review, 3(8), 11-28.

Prasad E. 2010. Financial Sector Regulation and Reforms in Emerging Markets: An Overview. Working Paper Cambridge: National Bureau of Economic Research.

Saidani, Basrah, M. Aulia Rachman, and Mohamad Rizan. (2013). Pengaruh Kualitas Produk Dan Desain Produk Terhadap Keputusan Pembelian Sepatu Olahraga Futsal Adidas Di Jakarta Timur. Jurnal Riset Manajemen Sains Indonesia, Vol. 4, No. 2.

Yang, Liu dan Zhang, Youtang. (2020). Digital Financial Inclusion and Sustainable Growth of Small and Micro Enterprises-Evidence Based on China's New Third Board Market Listed Companies. Sustainability Journal, 12, 3733; doi:10.3390/su12093733.

Yaron, J., Benjamin, M. P., \& Piprek, G. L. (2013). Rural Finance: Issue, Design, and Best Practices. Washington DC.

Zain, N. H. (2010). Keterkaitan Perbankan Syariah dengan Usaha Mikro Kecil Menengah (UMKM) di Indonesia. Dikta Ekonomi, 7(2), 146-158. 